Thorax (1955), 10, 183.

\title{
SURVIVAL AFTER LUNG RESECTION FOR BRONCHIAL CARCINOMA
}

\author{
BY \\ J. R. BIGNALL AND A. J. MOON \\ From the Brompton Hospital, the London Chest Hospital, and the Institute of Diseases of the Chest, \\ London
}

(RECEIVED FOR PUBLICATION MAY 19, 1955)

There are many reports of the experience of groups of patients with a bronchial carcinoma treated by lung resection. In this couniry, for instance, there are series recorded by Sellors, Cruickshank, and Billimoria (1947), Brock (1948), Mason (1949), Taylor and Waterhouse (1950), Price Thomas (1952), and Sellors (1955). But gross yearly survival rates may be a poor guide to prognosis in the individual patient if the duration of survival is greatly influenced by factors not common to all. We have investigated the effects on survival of some of these factors in a relatively large group of patients.

The patients were operated on at the Hospitals for Diseases of the Chest by the surgeons of the two hospitals and their assistants between 1940 and 1951. All with a histological diagnosis and a record of the cell type have been included. Records of 531 patients were available ; all but 13 (2\%) were followed for at least two years or until death. Three were lost sight of during the first two months, two in the third month, and four more in the remaining nine months of the first year.

The experience of the patients is expressed as the chances of surviving for each of the first five years after operation. The survival rates have been calculated by the life-table method, which makes full use of the available data where groups of patients have been treated over a period of years and observed for different lengths of time. The validity of the procedure depends on the mortality remaining unchanged throughout the period. This was not true of the immediate mortality after operation. The "operative mortality," arbitrarily defined as death within two months of operation, was high in the early years. Between 1940 and 1946 it was $19 \%$, but in $1947-49$ it fell to $16 \%$ and in the next two-year period to $10 \%$. The operative mortality must therefore be removed from the life-tables, both for investigating the factors influencing survival and for using the rates as a guide to the prognosis of patients operated on in the future. On the other hand, the experience of those who survived operation changed little during the 12 years (Table II). Thus, for the 114 survivors during $1940-46$ the chance of surviving two years was $47 \%$ and four years $34 \%$. In the next period the corresponding rates were $48 \%$ and $36 \%$ for 155 patients ; and for the period $1950-5147 \%$ and $35 \%$ for 184 patients. It appears justified, therefore, to combine the experience of all those who survived operation during the entire 12 years.

Some were reported to have died from causes other than cancer, and in some of these postmortem examination showed no recurrence or metastases. But unless there is a high proportion of necropsies it is impossible to estimate accurately the frequency of non-cancer deaths; no distinction is made in this investigation between death from cancer and death from other diseases. The mortality rates, therefore, are for deaths from all causes. Patients living at the time of the last report were considered to have been alive for half the particular year of observation. The survival rates for the fourth and later years are less likely to be accurate than those for the first three, as the yearly number of operations increased considerably during the later part of the period.

Yearly Survival Rates of the Whole Group

These are shown in Table I and Fig. 1. Four hundred and fifty-three patients survived the early post-operative period. The largest number of deaths occurred in the second three-month period, in which there was a $13 \%$ chance of dying. But if the patient survived a year the risk of dying in the subsequent three-month periods declined from $8 \%$ to $4 \%$ during the next two years. There was a $63 \%$ chance of surviving a year, $47 \%$ two years, $39 \%$ three years, and $33 \%$ five years. 
TABLE I

SURVIVAL RATES OF PATIENTS LIVING LONGER THAN TWO MONTHS AFTER OPERATION*

\begin{tabular}{c|c|c|c|c|c}
\hline $\begin{array}{c}\text { Interval } \\
\text { (Completed } \\
\text { Months from } \\
\text { Operation) }\end{array}$ & \multicolumn{2}{|c|}{ Last Report } & $\begin{array}{c}\text { “ At Risk } \\
\text { at Start } \\
\text { of } \\
\text { Interval }\end{array}$ & $\begin{array}{c}\text { Dead } \\
\text { Probability } \\
\text { of Dying } \\
\text { during } \\
\text { Interval (\%) }\end{array}$ & $\begin{array}{c}\text { Survival } \\
\text { Rate } \\
(\%)\end{array}$ \\
\hline $0-2$ & 27 & 2 & 453 & $6 \cdot 0$ & 94 \\
$3-5$ & 54 & 2 & 423 & $12 \cdot 7$ & 82 \\
$6-8$ & 40 & 2 & 367 & $10 \cdot 9$ & 73 \\
$9-11$ & 43 & & 326 & $13 \cdot 2$ & 63 \\
\hline $12-14$ & 22 & 1 & $282 \cdot 5$ & $7 \cdot 7$ & 58 \\
$15-17$ & 21 & 1 & $259 \cdot 5$ & $8 \cdot 1$ & 54 \\
$18-20$ & 14 & 2 & 237 & $5 \cdot 9$ & 51 \\
$21-23$ & 14 & & 222 & $6 \cdot 3$ & 47 \\
\hline $24-26$ & 11 & 7 & $204 \cdot 5$ & 54 & 45 \\
$27-28$ & 9 & 4 & 188 & 48 & 43 \\
$30-32$ & 8 & 6 & 174 & $4 \cdot 6$ & 41 \\
$33-35$ & 7 & 2 & 162 & $4 \cdot 3$ & 39 \\
\hline $36-47$ & 15 & 42 & 133 & $11 \cdot 3$ & 35 \\
\hline $48-59$ & 3 & 24 & 85 & $3 \cdot 5$ & 33 \\
\hline $60-71$ & 2 & 18 & 61 & $3 \cdot 3$ & 32 \\
$72-83$ & 2 & 14 & 43 & $4 \cdot 6$ & 31 \\
$84-95$ & 2 & 10 & 29 & $6 \cdot 9$ & 29 \\
$96-107$ & 2 & 7 & $18 \cdot 5$ & 11 & 25 \\
$108-119$ & 2 & 5 & $10 \cdot 5$ & 19 & 21 \\
\hline $120+$ & - & 6 & & & \\
\hline
\end{tabular}

* Proportions and rates based on less than 50 patients are printed in italics.

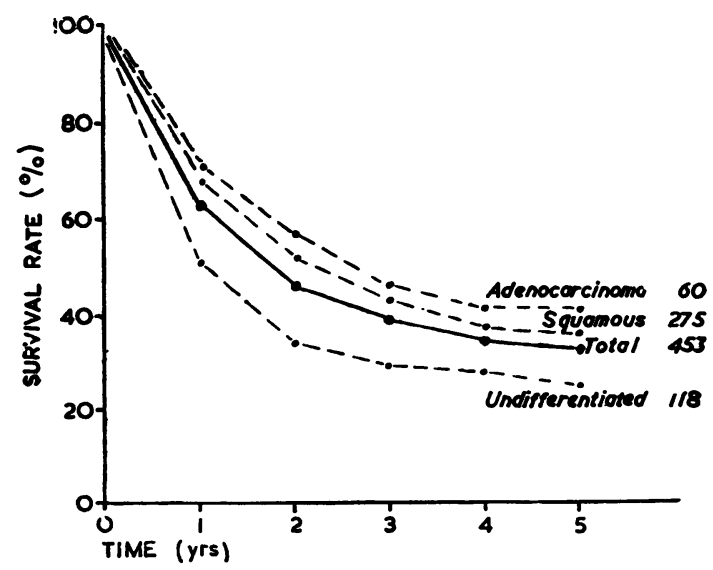

Fig. 1.-The survival rates in the three histological types.

\section{The Influence of Certain Factors on SuRVIVAL}

H.stological Type.-The recording of the histological type of a tumour depends on many variables. Different pathologists may give different opinions on the same section; and sections from different parts of a tumour may show different cell types and arrangements. It is to some extent, therefore, a matter of chance which label is assigned to a particular tumour. In this series the histological reports were given by several different pathologists during the 12 years, and the sections have not been re-examined for this investigation. Although there are undoubtedle many inconsistencies, it seems reasonable to exब pect that the broad classification into squamous undifferentiated, and adenocarcinoma (includings the columnar-cell type) will be sufficiently exacb for an approximate estimation of the influence of histological appearances on survival.

Two hundred and seventy-five were reported to have squamous carcinomas, and the survival rate was $52 \%$ for two years and $36 \%$ for five years (Table II, Fig. 1). The corresponding rates fo the 118 with undifferentiated tumours were $34 \%$ and $26 \%$. Such differences are unlikely to haves arisen by chance (Table VI). Only 60 had adeno-? carcinomas. The two-year rate was $57 \%$ and the five-year rate $41 \%$, but the latter is based ond relatively few patients. The experience of the squamous and adenocarcinoma groups was much the same ; and clearly to demonstrate any differ $\stackrel{\mathbb{D}}{7}$ ences that may exist between these types would require a much larger number of patients.

Mediastinal and Hilar Node Metastases.The influence of metastases in the regional lymphe nodes was investigated in two ways. Although grossly involved nodes may be readily recognized at operation, not all enlarged firm nodes contain metastases. The presence of metastases is, in practice, judged both from the surgeon's observa응 tion of the macroscopic appearances and the pathologist's report on the specimen he receives The patients operated on at one hospital were therefore divided into two groups according to the recorded opinion of the surgeon on the pre sence of metastases in the hilar and mediastinal lymph nodes. In the patients from the other hos-3 pital only the pathologist's report of involved nodes outside the lung was considered. In many cases, particularly in the early years, it was not clear whether the macroscopically malignant nodes removed at operation had been sectioned. On the other hand, there were several examples of re ported microscopic involvement of nodes around the pulmonary vessels when there was no recorq of these having been considered macroscop:callys involved at operation. It was therefore thoughtw that comparison between those with and withouk histological evidence of metastases would not be valid.

Adequate data on the surgeon's assessment of node metastases are available in 233 patients. One hundred of these did not appear to have regiona? metastases; and the two-year survival rate was $61 \%$, the five-year rate being $48 \%$ (Table II). On 
TABLE II

SURVIVAL RATES FOR FIRST 5 YEARS OF PATIENTS LIVING LONGER THAN 2 MONTHS AFTER OPERATION RELATED TO PERIOD OF OPERATION, HISTOLOGICAI TYPE, SIDE, LOBE, AGE, DURATION OF SYMPTOMS, SEX EXTENT OF RESECTION, AND PRESENCE OF ENLARGED NODES*

\begin{tabular}{|c|c|c|c|c|c|c|}
\hline & \multirow{2}{*}{ No. } & \multicolumn{5}{|c|}{$\begin{array}{c}\text { Chance of Surviving } \\
(\%)\end{array}$} \\
\hline & & Year & $\mid \begin{array}{c}2 \\
\text { Years }\end{array}$ & $\begin{array}{c}3 \\
\text { Years }\end{array}$ & Years & $\begin{array}{c}5 \\
\text { Years }\end{array}$ \\
\hline $\begin{array}{rll}\text { All patients } & \ldots & \ldots \\
1940-1946 & \ldots & \ldots \\
1947-1949 & \ldots & \ldots \\
1950-1951 & \ldots & \ldots\end{array}$ & $\begin{array}{l}453 \\
114 \\
155 \\
184\end{array}$ & $\begin{array}{l}63 \\
64 \\
64 \\
63\end{array}$ & $\begin{array}{l}47 \\
47 \\
48 \\
47\end{array}$ & $\begin{array}{l}39 \\
37 \\
41 \\
39\end{array}$ & $\begin{array}{l}35 \\
34 \\
36 \\
35\end{array}$ & $\begin{array}{r}33 \\
32 \\
35 \\
-\end{array}$ \\
\hline $\begin{array}{l}\text { Squamous } \ldots \\
\text { Adenocarcinoma } \\
\text { Undifferentiated }\end{array}$ & $\begin{array}{r}275 \\
60 \\
118\end{array}$ & $\begin{array}{l}68 \\
71 \\
51\end{array}$ & $\begin{array}{l}52 \\
57 \\
34\end{array}$ & $\begin{array}{l}43 \\
46 \\
29\end{array}$ & $\begin{array}{l}37 \\
41 \\
28\end{array}$ & $\begin{array}{l}36 \\
41 \\
26\end{array}$ \\
\hline $\begin{array}{l}\text { Right lung } \\
\text { Left ", }\end{array}$ & $\begin{array}{l}210 \\
243\end{array}$ & $\begin{array}{l}66 \\
61\end{array}$ & $\begin{array}{l}51 \\
44\end{array}$ & $\begin{array}{l}45 \\
37\end{array}$ & $\begin{array}{l}40 \\
33\end{array}$ & $\begin{array}{l}39 \\
31\end{array}$ \\
\hline $\begin{array}{l}\text { Right upper lobe } \\
\text { Squamous } \\
\text { Undifferentiated }\end{array}$ & $\begin{array}{l}76 \\
44 \\
19\end{array}$ & $\begin{array}{l}72 \\
78 \\
64\end{array}$ & $\begin{array}{l}57 \\
61 \\
58\end{array}$ & $\begin{array}{l}45 \\
47 \\
49\end{array}$ & $\begin{array}{l}43 \\
44 \\
49\end{array}$ & $\begin{array}{l}43 \\
44 \\
49\end{array}$ \\
\hline $\begin{array}{l}\text { Left upper lobe } \\
\text { Squamous } \\
\text { Undifferentiated }\end{array}$ & $\begin{array}{r}131 \\
78 \\
35\end{array}$ & $\begin{array}{l}67 \\
73 \\
51\end{array}$ & $\begin{array}{l}52 \\
60 \\
31\end{array}$ & $\begin{array}{l}43 \\
49 \\
26\end{array}$ & $\begin{array}{l}38 \\
42 \\
25\end{array}$ & $\begin{array}{l}36 \\
42 \\
25\end{array}$ \\
\hline $\begin{array}{l}\text { Right lower lobe } \\
\text { Squamous } \\
\text { Undifferentiated }\end{array}$ & $\begin{array}{r}114 \\
68 \\
31\end{array}$ & $\begin{array}{l}65 \\
72 \\
43\end{array}$ & $\begin{array}{l}50 \\
56 \\
29\end{array}$ & $\begin{array}{l}40 \\
46 \\
25\end{array}$ & $\begin{array}{l}34 \\
38 \\
21\end{array}$ & $\begin{array}{l}32 \\
36 \\
21\end{array}$ \\
\hline $\begin{array}{l}\text { Left lower lobe } \\
\text { Squamous } \ldots . . \text { Undifferentiated }\end{array}$ & $\begin{array}{r}105 \\
66 \\
29\end{array}$ & $\begin{array}{l}55 \\
57 \\
44\end{array}$ & $\begin{array}{l}36 \\
38 \\
22\end{array}$ & $\begin{array}{l}31 \\
33 \\
22\end{array}$ & $\begin{array}{l}27 \\
31 \\
22\end{array}$ & $\begin{array}{l}25 \\
28 \\
22\end{array}$ \\
\hline $\begin{array}{ccc}\text { Age less than } & 45 & \text { years } \\
45-49 & \ldots & \ldots \\
50-54 & \ldots & \ldots \\
55-59 & \ldots & \ldots \\
60-64 & \ldots & \ldots \\
65 \text { and over } & . . & .\end{array}$ & $\begin{array}{r}77 \\
81 \\
103 \\
92 \\
76 \\
24\end{array}$ & $\begin{array}{l}70 \\
56 \\
63 \\
62 \\
68 \\
62\end{array}$ & $\begin{array}{l}53 \\
39 \\
51 \\
42 \\
55 \\
45\end{array}$ & $\begin{array}{l}49 \\
34 \\
37 \\
35 \\
48 \\
26\end{array}$ & $\begin{array}{l}45 \\
29 \\
32 \\
32 \\
40 \\
26\end{array}$ & $\begin{array}{l}45 \\
27 \\
31 \\
30 \\
40 \\
26\end{array}$ \\
\hline 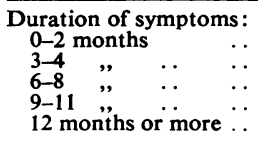 & $\begin{array}{r}71 \\
158 \\
97 \\
41 \\
71\end{array}$ & $\begin{array}{l}64 \\
62 \\
55 \\
75 \\
73\end{array}$ & $\begin{array}{l}53 \\
47 \\
39 \\
51 \\
54\end{array}$ & $\begin{array}{l}45 \\
40 \\
33 \\
34 \\
45\end{array}$ & $\begin{array}{l}42 \\
36 \\
31 \\
31 \\
34\end{array}$ & $\begin{array}{l}42 \\
33 \\
31 \\
27 \\
34\end{array}$ \\
\hline $\begin{array}{l}\text { Men } \\
\text { Women }\end{array}$ & $\begin{array}{r}412 \\
41\end{array}$ & $\begin{array}{l}62 \\
78\end{array}$ & $\begin{array}{l}46 \\
65\end{array}$ & $\begin{array}{l}38 \\
57\end{array}$ & $\begin{array}{l}33 \\
57\end{array}$ & $\begin{array}{l}31 \\
57\end{array}$ \\
\hline $\begin{array}{l}\text { Pneumonectomy } \\
\text { Lobectomy }\end{array}$ & $\begin{array}{r}379 \\
74\end{array}$ & $\begin{array}{l}61 \\
76\end{array}$ & $\begin{array}{l}46 \\
54\end{array}$ & $\begin{array}{l}38 \\
44\end{array}$ & $\begin{array}{l}33 \\
42\end{array}$ & $\begin{array}{l}32 \\
42\end{array}$ \\
\hline $\begin{array}{l}\text { Enlarged nodes } \\
\text { No }, ",\end{array}$ & $\begin{array}{l}133 \\
100\end{array}$ & $\begin{array}{l}44 \\
77\end{array}$ & $\begin{array}{l}27 \\
61\end{array}$ & $\begin{array}{l}14 \\
51\end{array}$ & $\begin{array}{l}12 \\
48\end{array}$ & $\begin{array}{l}11 \\
48\end{array}$ \\
\hline $\begin{array}{c}\text { Enlarged nodes. } \\
\text { monectomy- } \\
\text { Enlarged nodes. } \\
\text { tomy .. Lobec- } \\
. .\end{array}$ & $\begin{array}{r}113 \\
20\end{array}$ & $\begin{array}{l}44 \\
45\end{array}$ & $\begin{array}{l}25 \\
40\end{array}$ & $\begin{array}{l}21 \\
25\end{array}$ & $\begin{array}{l}18 \\
25\end{array}$ & $\begin{array}{l}16 \\
25\end{array}$ \\
\hline $\begin{array}{l}\text { No enlarged nodes. } \\
\text { Pneumonectomy } . . \\
\text { No enlarged nodes. } \\
\text { Lobectomy .. }\end{array}$ & $\begin{array}{l}70 \\
30\end{array}$ & $\begin{array}{l}74 \\
83\end{array}$ & $\begin{array}{l}64 \\
57\end{array}$ & $\begin{array}{l}53 \\
47\end{array}$ & $\begin{array}{l}49 \\
47\end{array}$ & $\begin{array}{l}49 \\
47\end{array}$ \\
\hline
\end{tabular}

* Proportions and rates based on less than 50 patients are printed in italics.

the other hand, of the 133 considered to have metastases, the corresponding rates were $27 \%$ and $11 \%$. The proportion with undifferentiated tumours, that is to say those known to have a lower survival rate, was the same in the two groups (Table IV). The differences are clearly significant and indicate the great effect of macroscopically evident regional nodes metastases on survival (Table VI).

Although some of those with histological evidence of metastases also had greatly enlarged nodes, many had been considered at operation to have no manifest extension of the tumour. The two-year survival rate of 58 patients with histologically demonstrated extrapulmonary node metastases was $46 \%$ and the five-year rate $25 \%$. The report of tumour tissue in the nodes, though of prognostic significance, does not indicate an inevitably poor outlook, for 27 of the 58 with this report were still alive two years after operation.

The Position of The Tumour.-In 210 the tumour was in the right lung and in 243 the left. The proportion of undifferentiated cancers was substantially the same in the two groups (Table III), as was the proportion with enlarged nodes in the sample investigated (Table IV). There were, however, differences in the survival rates. The two-year rate for those with a right-sided tumour was $51 \%$ compared with $44 \%$ for those on the left side; and the five-year rates were $39 \%$ and $31 \%$.

The survival rates have also been calculated for the different lobes of the lungs (Table II and Fig. 2). There were 76 in the right upper lobe with two- and five-year rates of $57 \%$ and $43 \%$, compared with $50 \%$ and $32 \%$ for the 114 with tumours in the right lower lobe. Similarly the left upper lobe with 131 cases had a higher survival rate, $52 \%$ and $36 \%$, than the left lower lobe, $36 \%$ and $25 \%$, with 105 cases. The survival rates both for squamous and undifferentiated tumours maintain the same pattern as those of the whole group. For example, for squamous tumours the

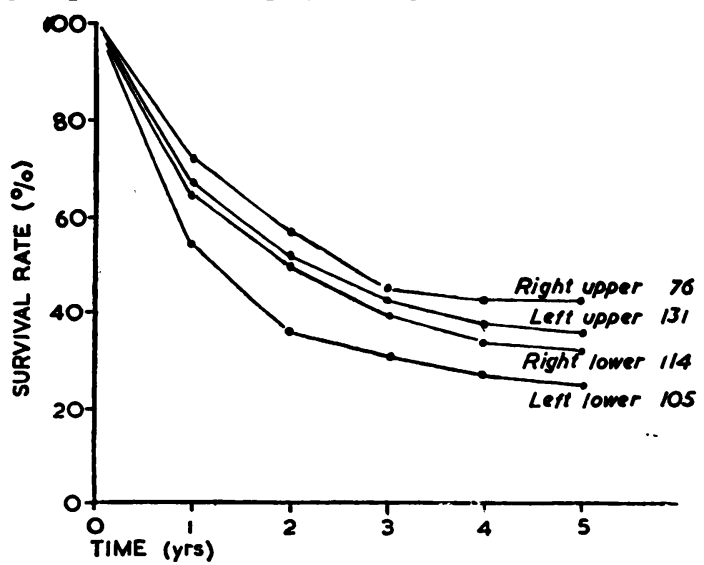

FIG. 2.-The survival rates in the upper and lower lobes of both lungs. 
two-year rates were $61 \%$ for the right upper lobe, $60 \%$ for the left upper lobe, $56 \%$ for the right lower lobe, and $38 \%$ for the left lower lobe, and the rates for undifferentiated tumours were $58 \%$, $31 \%, 29 \%$, and $22 \%$. However, the difference in survival between the two upper lobes is small and may well have been due to chance. So may that between the upper and lower lobes of the right lung.

The lowest survival rates were found with left lower lobe tumours, and the differences between this lobe and the others are much less likely to have been chance findings (Table VI). There were, moreover, insignificant differences in the distribution of histological types between the lobes, and only a very slightly higher proportion of left lower lobe tumours with enlarged nodes in the sample examined. It may be, therefore, that the observed differences in survival rates were indeed due to the situation of the tumour.

SEX.-There were only 41 women among the 453 patients surviving operation. Their two- and five-year survival rates were $65 \%$ and $57 \%$, compared with $46 \%$ and $31 \%$ for the men, although there was a higher proportion of women with undifferentiated tumours (Tables II and III). There were, on the other hand, probably fewer women with enlarged nodes, there being $42 \%$ compared with $59 \%$ in the sample examined. The difference in the survival rates is considerable and was probably not due to chance (Table VI). But with such a small number of women and such unequal distribution between the sexes of the two factors known to influence prognosis, it is impossible to be sure that the differences in mortality were due only to sex differences in the behaviour of the tumour.

AGE.-No regular pattern of survival in relation to the age of the patients was detected (Table II). Thus, the two-year rates ranged from 39\% for those between 45 and 49 years to $55 \%$ between 60 and 64, and the five-year rates from $27 \%$ to $40 \%$. But survival did not consistently decrease or increase with advancing age. The proportion with undifferentiated tumours was lower in those over 60 (Table III). This factor would tend to increase the survival rate; but, although the prognosis was indeed slightly better in those between 60 and 64 than in those between 45 and 60 the difference was small. Those under 45 had similar surival rates to those aged 60 to $64,53 \%$ for two years and $45 \%$ for five years.

The Duration of Symptoms before OperaTION.- It might be expected that the chances of surviving would vary inversely with the duration
TABLE III

HISTOLOGICAL TYPE RELATED TO PERIOD OF OPERATION, SITE OF TUMOUR, SEX AND AGE OF PATIENTS DURẢTION OF SYMPTOMS AND EXTENT OF OPERATION

\begin{tabular}{|c|c|c|c|c|c|c|c|c|}
\hline & & \multicolumn{2}{|c|}{ Squamous } & \multicolumn{2}{|c|}{$\begin{array}{c}\text { Adeno- } \\
\text { Carcinoma }\end{array}$} & \multicolumn{2}{|c|}{$\begin{array}{l}\text { Undifferen- } \\
\text { tiated }\end{array}$} & \multirow{2}{*}{ Total } \\
\hline & & No. & $\%$ & No. & /o & No. & $\%$ & \\
\hline All patient & $\cdots$ & 275 & 61 & 60 & 13 & 118 & 26 & 453 \\
\hline $\begin{array}{l}1940-1946 \\
1947-1949 \\
1950-\ldots\end{array}$ & $\begin{array}{l}\cdots \\
\cdots \\
\cdots\end{array}$ & $\begin{array}{r}73 \\
95 \\
107\end{array}$ & $\begin{array}{l}64 \\
61 \\
58\end{array}$ & $\begin{array}{l}11 \\
23 \\
26\end{array}$ & $\begin{array}{l}10 \\
15 \\
14\end{array}$ & $\begin{array}{l}30 \\
37 \\
51\end{array}$ & $\begin{array}{l}26 \\
24 \\
28\end{array}$ & $\begin{array}{l}114 \\
155 \\
184\end{array}$ \\
\hline $\begin{array}{l}\text { Right lung } \\
\text { Left , }\end{array}$ & $\begin{array}{l}\cdots \\
\cdots\end{array}$ & $\begin{array}{l}126 \\
149\end{array}$ & $\begin{array}{l}60 \\
61\end{array}$ & $\begin{array}{l}31 \\
29\end{array}$ & $\begin{array}{l}15 \\
12\end{array}$ & $\begin{array}{r}3 \\
65\end{array}$ & $\begin{array}{l}25 \\
27\end{array}$ & $\begin{array}{l}210 \\
243\end{array}$ \\
\hline \multicolumn{2}{|c|}{$\begin{array}{l}\text { Right upper lobe } \\
\text { Left ", } \\
\text { Right lower lobe } \\
\text { Left ", ", }\end{array}$} & $\begin{array}{l}44 \\
78 \\
68 \\
66\end{array}$ & $\begin{array}{l}58 \\
60 \\
60 \\
62\end{array}$ & $\begin{array}{l}13 \\
18 \\
15 \\
10\end{array}$ & $\begin{array}{r}17 \\
14 \\
13 \\
9\end{array}$ & $\begin{array}{l}19 \\
35 \\
31 \\
29\end{array}$ & $\begin{array}{l}25 \\
26 \\
27 \\
28\end{array}$ & $\begin{array}{r}76 \\
131 \\
114 \\
105\end{array}$ \\
\hline $\begin{array}{c}\text { Age less th } \\
45-49 \\
50-54 \\
55-59 \\
60-64 \\
65+ \\
\end{array}$ & $\begin{array}{r}\text { an } 45 \\
\ldots \\
\ldots \\
\ldots \\
\ldots \\
\ldots\end{array}$ & $\begin{array}{l}42 \\
50 \\
62 \\
53 \\
51 \\
17\end{array}$ & $\begin{array}{l}54 \\
62 \\
60 \\
58 \\
67 \\
71\end{array}$ & $\begin{array}{r}10 \\
9 \\
13 \\
11 \\
14 \\
3\end{array}$ & $\begin{array}{l}13 \\
11 \\
13 \\
12 \\
18 \\
12\end{array}$ & $\begin{array}{r}25 \\
22 \\
28 \\
28 \\
11 \\
4\end{array}$ & $\begin{array}{l}32 \\
27 \\
27 \\
30 \\
15 \\
17\end{array}$ & $\begin{array}{r}77 \\
81 \\
103 \\
92 \\
76 \\
24\end{array}$ \\
\hline $\begin{array}{c}\text { Duration } \\
\text { symptom } \\
0-2 \text { mo } \\
3-5 \\
6-8 \\
9-11 \\
12+ \\
\end{array}$ & $\begin{array}{l}\text { f } \\
\text { is: } \\
\text { nths } \\
\text {, } \ldots \\
, \ldots \\
\text {, }\end{array}$ & $\begin{array}{l}45 \\
94 \\
59 \\
26 \\
44\end{array}$ & $\begin{array}{l}63 \\
61 \\
61 \\
63 \\
62\end{array}$ & $\begin{array}{r}5 \\
21 \\
12 \\
9 \\
11\end{array}$ & $\begin{array}{r}7 \\
12 \\
12 \\
23 \\
15\end{array}$ & $\begin{array}{r}21 \\
43 \\
26 \\
6 \\
16\end{array}$ & $\begin{array}{l}30 \\
27 \\
27 \\
14 \\
23\end{array}$ & $\begin{array}{r}71 \\
158 \\
97 \\
41 \\
71\end{array}$ \\
\hline $\begin{array}{l}\text { Men . . } \\
\text { Women }\end{array}$ & $\begin{array}{l}\cdots \\
\cdots\end{array}$ & $\begin{array}{r}260 \\
15\end{array}$ & $\begin{array}{l}63 \\
37\end{array}$ & $\begin{array}{r}51 \\
9\end{array}$ & $\begin{array}{l}12 \\
22\end{array}$ & $\begin{array}{r}101 \\
17\end{array}$ & $\begin{array}{l}25 \\
41\end{array}$ & $\begin{array}{r}412 \\
41\end{array}$ \\
\hline $\begin{array}{l}\text { Pneumonec } \\
\text { Lobectomy }\end{array}$ & $\begin{array}{c}\text { ctomy } \\
\quad .\end{array}$ & $\begin{array}{r}237 \\
38\end{array}$ & $\begin{array}{l}63 \\
51\end{array}$ & $\begin{array}{l}42 \\
18\end{array}$ & $\begin{array}{l}11 \\
24\end{array}$ & $\begin{array}{r}100 \\
18\end{array}$ & $\begin{array}{l}26 \\
25\end{array}$ & $\begin{array}{r}379 \\
74\end{array}$ \\
\hline
\end{tabular}

of symptoms before operation. This was true in this series for duration of symptoms up to eight months, the two-year rate being $53 \%$ for those with symptoms for less than three months and $39 \%$ for six to eight months. But for longer durations the chance of survival appeared to improve $\stackrel{\otimes}{x}$ and became $54 \%$ for two years in those who had o had symptoms for a year or more. This could hardly have been due to the slight differences in 0 the proportions of squamous tumours and the finding of enlarged nodes (Tables III and IV). It 을 is probable that those who are still fit enough for $D$ operation and who have no overt metastases nine months or longer from the start of illness tend to have slowly growing, localized tumours. The or lowest survival rates occurred in those with his- N tories of six to eight months, which appears to be $N$ the time at which there is the most chance of the cancer being disseminated. For instance, among the patients with a bronchial carcinoma seen at the Brompton and Royal Marsden Hospitals dur- $-\infty$ ing 1951 the proportion with evidence of metastases when first seen was highest in those with five ${ }_{0}^{-}$ months' history (Bignall, 1955a). A similar rela-ब्षे tion between survival rate and duration of symp-胥 toms before diagnosis is seen in those who are 
TABLE IV

PRESENCE OF ENLARGED MEDIASTINAL NODES AT OPERATION RELATED TO HISTOLOGICAL TYPE AND SITE OF TUMOUR, PERIOD AND EXTENT OF OPERATION AGE AND SEX OF PATIENTS, AND DURATION OF SYMP-

\begin{tabular}{|c|c|c|c|c|c|}
\hline & \multicolumn{2}{|c|}{$\begin{array}{l}\text { Without } \\
\text { Enlarged Nodes }\end{array}$} & \multicolumn{2}{|c|}{$\begin{array}{l}\text { With } \\
\text { Enlarged Nodes }\end{array}$} & \multirow{2}{*}{ Total } \\
\hline & No. & $\%$ & No. & $\%$ & \\
\hline All patients & 100 & 43 & 133 & 57 & 233 \\
\hline $\begin{array}{l}\text { Squamous } \\
\text { Undifferentiated } \ldots \\
\text { Adenocarcinoma }\end{array}$ & $\begin{array}{l}64 \\
26 \\
10 \\
\end{array}$ & $\begin{array}{l}43 \\
46 \\
37 \\
\end{array}$ & $\begin{array}{l}85 \\
31 \\
17\end{array}$ & $\begin{array}{l}57 \\
54 \\
63\end{array}$ & $\begin{array}{r}149 \\
57 \\
27 \\
\end{array}$ \\
\hline $\begin{array}{l}\text { Right lung } \\
\text { Left } \quad, . . .\end{array}$ & $\begin{array}{l}46 \\
54\end{array}$ & $\begin{array}{l}43 \\
43\end{array}$ & $\begin{array}{l}61 \\
72 \\
\end{array}$ & $\begin{array}{l}57 \\
57\end{array}$ & $\begin{array}{l}107 \\
126 \\
\end{array}$ \\
\hline 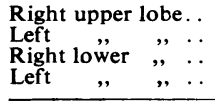 & $\begin{array}{l}19 \\
31 \\
25 \\
22\end{array}$ & $\begin{array}{l}46 \\
46 \\
43 \\
38\end{array}$ & $\begin{array}{l}22 \\
36 \\
33 \\
36\end{array}$ & $\begin{array}{l}54 \\
54 \\
57 \\
62\end{array}$ & $\begin{array}{l}41 \\
67 \\
58 \\
58\end{array}$ \\
\hline $\begin{array}{cc}\text { Year of operation: } \\
1940-1946 & . \\
1947-1949 & \ldots \\
1950-1951 & . \\
\end{array}$ & $\begin{array}{l}30 \\
34 \\
36\end{array}$ & $\begin{array}{l}55 \\
42 \\
36\end{array}$ & $\begin{array}{l}24 \\
46 \\
63\end{array}$ & $\begin{array}{l}45 \\
58 \\
64\end{array}$ & $\begin{array}{l}54 \\
80 \\
99\end{array}$ \\
\hline $\begin{array}{l}\text { Pneumonectomy } \\
\text { Lobectomy }\end{array}$ & $\begin{array}{l}70 \\
30\end{array}$ & $\begin{array}{l}38 \\
60\end{array}$ & $\begin{array}{r}113 \\
20\end{array}$ & $\begin{array}{l}62 \\
40\end{array}$ & $\begin{array}{r}183 \\
50\end{array}$ \\
\hline $\begin{array}{ccc}\text { Age less } & \text { than } & 45 \\
45-49 & . & \\
50-54 & . & . \\
55-59 & . & . \\
60-64 & . & . \\
65+ & . & . \\
\end{array}$ & $\begin{array}{r}20 \\
16 \\
16 \\
26 \\
17 \\
7\end{array}$ & $\begin{array}{l}46 \\
43 \\
33 \\
52 \\
39 \\
54 \\
\end{array}$ & $\begin{array}{r}23 \\
21 \\
33 \\
24 \\
26 \\
6\end{array}$ & $\begin{array}{l}54 \\
57 \\
67 \\
48 \\
61 \\
46\end{array}$ & $\begin{array}{l}43 \\
37 \\
49 \\
50 \\
43 \\
13\end{array}$ \\
\hline $\begin{array}{lll}\text { Men } & \cdots & \ldots \\
\text { Women } & \cdots & . \\
\end{array}$ & $\begin{array}{l}89 \\
11 \\
\end{array}$ & $\begin{array}{l}41 \\
58 \\
\end{array}$ & $\begin{array}{r}125 \\
8\end{array}$ & $\begin{array}{r}59 \\
42 \\
\end{array}$ & $\begin{array}{r}214 \\
19\end{array}$ \\
\hline $\begin{array}{c}\text { Duration of } \\
\text { symptoms: } \\
0-2 \text { months }\end{array}$ & $\begin{array}{r}21 \\
38 \\
19 \\
8 \\
14\end{array}$ & $\begin{array}{l}48 \\
42 \\
44 \\
38 \\
41\end{array}$ & $\begin{array}{l}23 \\
53 \\
24 \\
13 \\
20\end{array}$ & $\begin{array}{l}52 \\
58 \\
56 \\
62 \\
59\end{array}$ & $\begin{array}{l}44 \\
91 \\
43 \\
21 \\
34\end{array}$ \\
\hline
\end{tabular}

* Proportions and rates based on less than 50 patients are printed in italics.

not treated. In a series of 255 untreated patients the median survival time after diagnosis was five months in those who had had symptoms for less than two months; but it fell to three months in the group with four to five months' illness before diagnosis, and rose again to seven months in patients with symptoms for a year or longer (Bignall, 1955b).

The chances of surviving five years were much the same in all groups except those with very short histories, suggesting that death may have occurred later in those with long histories because of the slow growth of the malignant tissue. The proportion in whom the growth was entirely eliminated probably depended little on the duration of symptoms before operation.

The EXTENT OF Operation.-With such a varied group of patients operated on during a period of 12 years by many different surgeons it is impossible to relate survival to small technical differences. Seventy-four had a lobectomy and 379 a pneumonectomy. The two- and five-year rates for those having a lobectomy were $54 \%$ and $42 \%$ compared with $46 \%$ and $32 \%$ after pneumonectomy (Table II). But the differences cannot be attributed to the extent of the resection. The proportion of undifferentiated tumours in the two groups was similar (Table III). But the sample in which the presence of gross evidence of metastases was investigated suggests that many more who had a lobectomy (as might be expected) had no evidence of node involvement (Table IV). Sixty per cent. having a lobectomy had no manifestly enlarged nodes compared with only $38 \%$ of those who had a pneumonectomy. The twoand five-year survival rates after pneumonectomy when no enlarged nodes were recorded were $64 \%$ and $49 \%$ (Fig. 3). These rates differ little from those following lobectomy without enlarged nodes $-57 \%$ and $47 \%$. Among those with enlarged

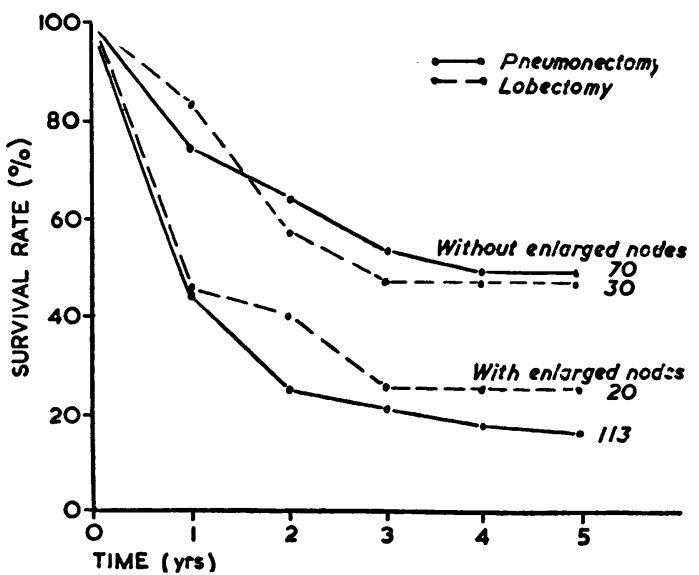

FIG. 3.-The survival rates after pneumonectomy and lobectomy of patients with and without enlarged extrapulmonary nodes.

nodes the rates were slightly higher in the lobectomy group, $40 \%$ and $25 \%$ compared with $25 \%$ and $16 \%$. It seems reasonable to conclude that there is no convincing evidence that the chances of survival of those who lived through the immediate post-operative period were materially affected by the extent of resection the surgeon considered advisable for the particular patient. On the other hand, there was a clear difference in operative mortality.

Operative Mortality.-The operative mortality decreased considerably during the 12 years from 1940 to 1951 . In the last two years it was $10 \%$, there being 21 deaths in 205 patients (Table $\mathrm{V})$. During this period none of the 42 patients who had a lobectomy died within two months of 
TABLE V

OPERATIVE MORTALITY DURING 1950 AND 1951 RELATED TO EXTENT OF OPERATION, SIDE OF TUMOUR, AND AGE OF PÁTIENTS

\begin{tabular}{|c|c|c|c|c|}
\hline & & \multirow{2}{*}{ Total } & \multicolumn{2}{|c|}{ Died in First Two Month } \\
\hline & & & No. & $\%$ \\
\hline 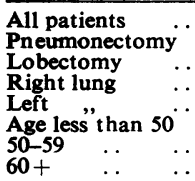 & $\begin{array}{l}\ldots \\
\cdots \\
\cdots \\
\cdots \\
\cdots \\
\cdots \\
\cdots\end{array}$ & $\begin{array}{r}205 \\
163 \\
42 \\
96 \\
109 \\
58 \\
87 \\
60\end{array}$ & $\begin{array}{r}21 \\
21 \\
0 \\
12 \\
9 \\
4 \\
9 \\
8\end{array}$ & $\begin{array}{r}10 \\
13 \\
0 \\
12 \\
8 \\
7 \\
10 \\
13\end{array}$ \\
\hline
\end{tabular}

OPERATIVe Mortality:

Pneumonectomy and lobectomy $\mathbf{P}=\mathbf{0 . 0 1 6}$ by exact test of significance

Right and left sides

$\chi^{2}=0.59$ using Yate's correction for small numbers

Age $\chi_{n=1}^{2}=0.59$ using Yate's correct

$\chi^{2}=0.95 \quad \mathrm{n}=2 \quad 0.7>\mathrm{P}>0.5$

TABLE VI

TESTS OF SIGNIFICANCE ON TWO-YEAR SURVIVAL RATES

\begin{tabular}{|c|c|c|c|c|c|}
\hline & $\begin{array}{c}\text { 2-year } \\
\text { Rate (\%) }\end{array}$ & $\mid \begin{array}{c}\text { Standard } \\
\text { Error }\end{array}$ & $\begin{array}{c}\text { Differ- } \\
\text { ence }\end{array}$ & $\begin{array}{c}\text { Standard } \\
\text { Error of } \\
\text { Differ- } \\
\text { ence }\end{array}$ & $\begin{array}{c}\text { Differ- } \\
\text { ence / } \\
\text { Standard } \\
\text { Error }\end{array}$ \\
\hline $\begin{array}{l}\text { Squamous } \\
\text { Undifferentiated } \ldots\end{array}$ & $\begin{array}{l}52 \cdot 0 \\
33 \cdot 7\end{array}$ & $\begin{array}{l}3 \cdot 0 \\
4 \cdot 6\end{array}$ & \} 18.3 & 5.5 & $3 \cdot 3$ \\
\hline $\begin{array}{l}\text { Without enlarged } \\
\text { nodes } \ldots \\
\text { With enlarged nodes }\end{array}$ & $\begin{array}{l}61 \cdot 5 \\
27 \cdot 3\end{array}$ & $\begin{array}{l}5.0 \\
3.9\end{array}$ & $34 \cdot 2$ & $6 \cdot 3$ & $5 \cdot 3$ \\
\hline $\begin{array}{l}\text { Right upper lobe. } \\
\text { Left }, ", \quad \ldots\end{array}$ & $\begin{array}{l}57 \cdot 2 \\
51 \cdot 6\end{array}$ & $\begin{array}{l}5 \cdot 7 \\
4 \cdot 3\end{array}$ & 55.6 & $7 \cdot 1$ & 0.8 \\
\hline $\begin{array}{l}\text { Right lower lobe } \\
\text { Left }, \quad " \quad \ldots\end{array}$ & $\begin{array}{l}50 \cdot 1 \\
36 \cdot 0\end{array}$ & $\begin{array}{l}4 \cdot 8 \\
4 \cdot 7\end{array}$ & \} $14 \cdot 1$ & 6.8 & $2 \cdot 1$ \\
\hline $\begin{array}{c}\text { Right upper lobe } \\
, \quad \text { lower }, \ldots\end{array}$ & $\begin{array}{l}57 \cdot 2 \\
50 \cdot 1\end{array}$ & $\begin{array}{l}5 \cdot 7 \\
4 \cdot 8\end{array}$ & \} $7 \cdot 1$ & $7 \cdot 5$ & 0.9 \\
\hline $\begin{array}{cc}\text { Left upper lobe } & . . \\
\text { " lower }, & \end{array}$ & $\begin{array}{l}51 \cdot 6 \\
36 \cdot 0\end{array}$ & $\begin{array}{l}4 \cdot 3 \\
4 \cdot 7\end{array}$ & \} $15 \cdot 6$ & $6 \cdot 4$ & 2.4 \\
\hline $\begin{array}{lll}\text { Men } & \ldots & \ldots \\
\text { Women } & \ldots & \ldots\end{array}$ & $\begin{array}{l}45 \cdot 7 \\
56 \cdot 2\end{array}$ & $\begin{array}{l}2 \cdot 4 \\
7 \cdot 5\end{array}$ & \} 19.5 & 7.9 & $2 \cdot 4$ \\
\hline
\end{tabular}

operation compared with $21(13 \%)$ of the 163 who had a pneumonectomy. Moreover, during the whole 12-year period only one of the 74 patients treated by lobectomy died in the early post-operative period. The mortality during 1950 and 1951 was $7 \%$ in those under 50 years of age, $10 \%$ in the sixth decade, and $13 \%$ in those over 60 . Although these differences are slight, it might be expected that the immediate risk of the operation would increase with age. The operative mortality was higher in those who had a resection done on the right side, being $12 \%$ compared with $8 \%$ on the left side. Following pneumonectomy the mortality was $16 \%$ on the right and $10 \%$ on the left. But both differences are small and may have been due to chance (Table V). It is unlikely that the early prognosis is affected by the side of the lesion.

\section{Discussion}

The poorer prognosis of undifferentiated tumours after lung resection is well known (Adams, 1948 ; McDonald, McBurney, Carlisle, and Patton, 1951 ; Borrie, 1952 ; Kirklin, McDonald, Clagett, Moersch, and Gage, 1955). So, too, is the considerable influence of metastases in the regional nodes on survival (Overholt and Schmidt, 1949 ; Churchill, Sweet, Soutter, and Scannel, 1950 ; Moore, 1951 ; Carlisle, McDonald, and Harrington, 1951 ; Thompson, 1952 ; Borrie, 1952 ; Ochsner, Ray, and Acree, 1954).

Carlisle and others (1951), from a study of 68 patients with squamous tumours at the Mayo Clinic, concluded that the prognosis was worse when the tumour was in the left lung. Borrie (1952) reported that eight of 13 patients alive three years after operation had had upper lobe lesions, although there had been a greater proportion of lower lobe tumours among the 72 resected. Our investigation also suggests that lower lobe tumours cause death within five years more frequently than those in the upper lobe, the difference between the right and left lungs being largely due to the low survival rate with tumours of the left lower lobe.

A slightly better prognosis with upper lobe tumours might merely be due to certain factors affecting selection for operation. Owing to the nearness of the primary to the supraclavicular nodes, the recurrent laryngeal nerve on the left and the superior vena cava on the right, it might be expected that more patients with upper lobe tumours would be judged unfit for exploration and therefore for resection. In those with lower lobe tumours involvement of regional nodes may have to be much greater before it becomes manifest. That such selection takes place is suggested by the study of 637 unselected patients seen at the Brompton and Royal Marsden Hospitals during 1951 and 1952. The bronchial location of the tumour was known in 505 cases. Two hundred and twenty-seven had cancers in the upper lobe ; $53(23 \%)$ had clinical or radiographic evidence of metastases when they were first examined at the hospitals, and $60(26 \%)$ had a resection. On the other hand, only $27(16 \%)$ of 166 with lower lobe cancers had manifest metastases and 57 (34\%) had a resection. Furthermore, Borrie (1952) found that there was more node involvement in the resected specimens when the primary was in 
the lower lobes. Those with upper lobe tumours who have the lung resected are probably, as a group, in a less advanced stage of the disease than those with lower lobe tumours, and the result of operation would be expected to be better.

A possible explanation of the differences between the right and left lower lobes-and to a less extent between the upper lobes-may be found in the anatomy of the lymphatics. Rouvière (1932) states that the lymphatics from the lower third of the left lung, as well as some of the vessels from the middle third, drain through the bifurcation lymph nodes into the right paratracheal chain. Warren and Drinker (1942) demonstrated in dogs that the greater part of the lymph from both lungs eventually passed into the vessels in the right paratracheal region; only a small amount from the left lung entered the blood stream from the left paratracheal system. The distribution of metastases could not be expected to follow strictly the physiological path of the lymph, for once a pathway becomes blocked by tumour the lymph stream is probably diverted into other channels. McCort and Robbins (1951) investigated the site of the metastases in 115 patients who had a thoracotomy for bronchial carcinoma. Although 11 of 22 with right upper lobe tumours had right paratracheal metastases, only two of 32 with left upper lobe tumours had metastases in the left paratracheal nodes and three had involvement of nodes on the right side. There was, however, no similar suggestion of crossed dissemination from left lower lobe tumours. But investigation of the spread of lung cancer in the mediastinum clearly requires postmortem examination, and evidence derived only from clinical, radiographic, and operative findings is incomplete. There is certainly some clinical evidence that crossed dissemination occurs from left-sided tumours. For instance, superior vena caval obstruction can be caused by a tumour in the left lung; and there was one such case in 24 treated for this complication in the patients seen at the Brompton and Royal Marsden Hospitals during 1951 and 1952. Moreover, metastases in the right paratracheal nodes occasionally occur after a left pneumonectomy.

In the 637 patients seen in 1951 and 1952 there was no evidence of the selection of less advanced cases for operation among those with right lower lobe tumours. Thus, 83 had tumours in this lobe and only seven $(8 \%)$ had manifest metastases at the first examination ; $33(40 \%)$ had a resection. There were, on the other hand, $20(24 \%)$ with metastases among 83 with left lower lobe cancers : and $24(29 \%)$ of these had a resection. It may be that the low survival rate of those with left lower lobe tumours is largely due to some of them having tumour tissue in the right upper mediastinal nodes, which are, of course, inaccessible at operation. This factor may be less important in the left upper lobe tumours if the lymph tends to take the more direct route by the left paratracheal chain. This explanation of the findings is, of course, merely a hypothesis. There may be many other factors contributing.

The risk of death in a particular patient cannot be accurately estimated. But the experience of this large group suggests that the chances of surviving the early period after operation may be of the order of $90 \%$ and of surviving each successive year to five years, $55 \%, 40 \%, 35 \%$, and $30 \%$. The chances are increased by there being no macroscop:cally involved nodes, the tumour being of the squamous or adenocarcinoma type, and in the upper lobes, particularly on the right side. The prognosis may be better in those with a very short or very long history and may possibly be better in women. The immediate risk is less after a lobectomy and in younger patients.

\section{SUMmaRY}

We have studied the duration of life after lung resection for bronchial carcinoma and investigated the effects of various factors on survival in a group of 531 patients treated at the Hospitals for Diseases of the Chest between 1940 and 1951 .

Four hundred and fifty-three survived the early post-operative period. Their chance of surviving one year was $63 \%$, two years $47 \%$, and five years $33 \%$.

The two- and five-year rates for those reported to have squamous tumours was $52 \%$ and $36 \%$ compared with $34 \%$ and $26 \%$ for those with undifferentiated growths.

The apparent involvement of the mediastinal nodes at operation had a considerable influence on survival. The two- and five-year rates for those without enlarged nodes were $61 \%$ and $48 \%$, but for those with enlarged nodes the rates were $27 \%$ and $11 \%$.

The prognosis appeared to depend to some extent on the situation of the tumour. The highest survival rates were observed with cancers of the right upper lobe, the two-year rate being $57 \%$. The left upper and right lower lobes had similar though slightly lower rates. But the two-year rate with cancers of the left lower lobe was significantly lower, being only $36 \%$. 
No regular pattern of survival in relation to age was detected.

The prognosis was better in women than in men.

The survival rates were lower in those with symptoms for six to eight months than in those with either shorter or longer histories.

The observed differences in survival rates following pneumonectomy and lobectomy could be largely attributed to the smaller proportion with involved mediastinal nodes among those having a lobectomy.

The operative mortality decreased from $19 \%$ between 1940 and 1946 to $10 \%$ in 1950 and 1951 . No patient during these two years died after a lobectomy, compared with $13 \%$ after pneumonectomy. The operative mortality increased with age.

We are indebted to the Nedical Committees of the Brompton Hospital, the London Chest Hospital, and the Royal Marsden Hospital for permission to use the records of the hospitals and to publish this report; and to the consultant physicians and surgeons for allowing us to follow up and study their patients. We are grateful to Mr. P. M. Payne, Statistician to the Royal Marsden Hospital, for his advice.

\section{REFERENCES}

Adams, R. (1948). J. thorac. Surg., 17, 306.

Bignall, J. R. (1955a). Lancet, 2, 210.

- (1955b). Ibid., 1, 786.

Borrie, J. (1952). Ann. roy. Coll. Surg., 10, 165.

Brock, R. C. (1948). Brit. med. J., 2, 737. J. thorac. Surg., 22, 74 .

Churchill, E. D., Sweet, R. H., Soutter, L., and Scannell, J. G. (1950). Ibid., $20,349$.

Kirklin, J. W., McDonald, J. R., Clagett, O. T., Moersch, H. J., and Gage, R. P. (1955). Surg. Gynec. Obstet., 1 $0,429$.

Mason, G. A. (1949). Lancet, 2, 587.

McCort, J. J., and Robbins, L. L. (1951), Radiology, 57, 339. (1951). J. thorac. Surg., 22, 62.

Moore, R. L. (1951). Cancer, 4, 663. Ochsner, A., Ray, C. J., and Acree, P. W. (1954). Amer. Rev. $\mathrm{J}$
Tuberc., 70, 763 .

Overholt, R. H., and Schmidt, I. C. (1949). New Engl. J. Med., 2 10, 491.

Rouvière, H. (1932). Anatomie des lymphatiques de l'homme. Masson, Paris.

Sellors, T. H. (1955). Brit. med. J., 1, 445.

Cruickshank, G., and Billimoria, B. R. (1947). Lancet, 2, 119.

Taylor, A. B., and Waterhouse, J. A. H. (1950). Thorax, 5, 257.

Thomas, C. Price (1952). Ann. roy. Coll. Surg. Engl., 11, 205.

Thompson, V. C. (1952). In Diseases of the Chest, Vol. 2, p. 329. Ed. by G. Marshall and K. M. A. Perry. Butterworth, London.

Warren, M. F., and Drinker, C. K. (1942). Amer. J. Physiol., 136, G 207. 